\title{
Effects of Seed Priming with Zinc Sulfate on Nutritional Enrichment and Biochemical Fingerprints of Momordica charantia
}

\author{
Shazia Anwer Bukhari ${ }^{D},{ }^{1}$ Nabila Farah, ${ }^{1}$ Saqib Mahmood, ${ }^{2}$ Javaria Altaf, \\ and Ghulam Mustafa ${ }^{1}{ }^{1}$ \\ ${ }^{1}$ Department of Biochemistry, Government College University, Faisalabad 38000, Pakistan \\ ${ }^{2}$ Department of Botany, Government College University, Faisalabad 38000, Pakistan \\ ${ }^{3}$ Department of Zoology, Government College University, Faisalabad-38000, Pakistan
}

Correspondence should be addressed to Ghulam Mustafa; gmustafa_uaf@yahoo.com

Received 2 February 2021; Revised 10 May 2021; Accepted 13 May 2021; Published 26 May 2021

Academic Editor: Nasim Ahmad Yasin

Copyright ( 2021 Shazia Anwer Bukhari et al. This is an open access article distributed under the Creative Commons Attribution License, which permits unrestricted use, distribution, and reproduction in any medium, provided the original work is properly cited.

\begin{abstract}
Zinc is an essential element for plant growth and development as it plays an important role in various metabolic processes with nutritional enrichment. The treatment with zinc sulfate is also economic. Momordica charantia is an economically important medicinal plant reported for a range of pharmaceutical and pharmacological properties. In this study, nutripriming with zinc sulfate $(0.1 \%, 0.2 \%$, and $0.3 \%$ solution) was applied to $M$. charantia seeds to optimize better dose. Based upon seedling establishment, $0.3 \%$ zinc sulfate was selected for final field experiment with randomized complete block design (RCBD) with five replications. Improved germination percentage, vigor, total soluble sugars, chlorophyll-a, chlorophyll-b, total chlorophyll content, and peroxidase activity were observed variably in leaves, fruit, and peel. Other nutritive components showed maintenance in fruits of treated plants indicating that the treatment did not cause any nutritive loss. Antimicrobial activity of leaves (in terms of the minimum inhibitory concentration) against Staphylococcus aureus and Pseudomonas aeruginosa was positively correlated with sinapic acid, vanillic acid, cinnamic acid, syringic acid, chlorogenic acid, benzoic acid, and ferulic acid. It has been concluded from this study that seed priming with zinc sulfate can improve seedling establishment, photosynthetic pigments, and stable nutritive value. Therefore, zinc from zinc sulfate priming has been proved as a beneficial fertilizer for $M$. charantia plant growth, yield, and nutraceutical potential.
\end{abstract}

\section{Introduction}

Seed priming is one of the promising techniques that impart positive effect upon plant growth, yield and metabolism. Pre-sowing seed treatments range from hydropriming, chemical, and biological to physical ones [1]. Improved seed performance in the field has been observed in response to these priming agents in terms of improved germination rate, metabolic pool, and stress-tolerance amongst all halopriming being comparatively easy to manage by a farmer is practiced more than other strategies $[2,3]$.
Zinc is a micronutrient with versatile contributions in plant physiology. It participates in regulation of different enzymes of primary and secondary metabolism and particularly related to photosynthesis and hormonal regulation. For years, plant scientists and farmers have been working on zinc supplementation. Major emphasis has been upon addition of zinc salts in rooting medium [4]. In recent literature, there has been focus upon different zinc nanoparticles too [5]. Root supplementation needs bulk of chemicals and therefore becomes expensive and non-friendly for environment. Nanoparticles need expensive series of technical 
work before plant growth. Hence, seed priming with zinc salts may be a better option being economic and ecofriendly.

Momordica charantia (bitter gourd) has God-gifted nutraceuticals and antioxidants. Therefore, extracts of $M$. charantia have been reported with decreasing blood sugar level in diabetes type II patients. Bitter gourd improves the metabolic problems and has positive effects on the glucose metabolism. Because of high antioxidant concentration, the bitter gourd extract has the ability to inhibit the growth of cancer cells as antioxidants protect cells from the damage caused by free radicals, environmental toxins, and poor nutrition. $a$ and $\beta$ carotene, zeaxanthin, and lutein are the antioxidants which are present in great amounts in bitter gourd [6]. A rich quantity of vitamin A also occurs with these antioxidants that protects the body from free radicals and prevents premature aging and other problems [7-9]. Our research group has formerly explored the antimicrobial potential of M. charantia leaf extracts against Staphylococcus aureus and Pseudomonas aeruginosa under the influence of magneto priming [8]. It was hypothesized that the seed priming with zinc sulfate could modulate primary and secondary metabolism of $M$. charantia and hence improves nutraceutical value of plants in terms of antimicrobial, antioxidant, and antiglycation potential.

\section{Materials and Methods}

The seeds of a local race of $M$. charantia were collected from Ayub Agricultural Research Institute (AARI), Faisalabad, Pakistan. Seeds were taxonomically identified and confirmed from the Department of Botany, Government College University Faisalabad, Pakistan.

2.1. Pilot Experiment. A lab experiment was planned for screening better dose of $\mathrm{ZnSO}_{4} \cdot 7 \mathrm{H}_{2} \mathrm{O}$ (Sigma-Aldrich, analytical grade, purity $>99 \%$ ) as priming agent. $M$. charantia seeds (approx. $30 \mathrm{~g}$ ) were subjected for presowing seed treatments with zinc sulfate (unprimed, hydroprimed, $0.1 \%, 0.2 \%$, and $0.3 \%$ solution) for 12 hours. The seeds were completely dipped in the solutions. Seeds were sown in soil filled glass pots, five replicates, and completely randomized design. Selection was made on the basis of seedling establishment in terms of seed fresh and dry biomass and germination percentage.

2.1.1. Germination Percentage. Incubation proportion of emergence was calculated at the end of $7^{\text {th }}$ day of incubation test by the process designated by Ijaz et al. [10].

$$
G p=\left(\frac{N g}{N p}\right) \times 100
$$

where $N g$ is the last number of emerged seeds and $N p$ is the total number of seeds sown.

2.1.2. Mean Germination Time. Mean growth time (MGT) in days was calculated as follows:

$$
M G T=\frac{\sum(D n)}{\sum n},
$$

where $n$ is number of seeds germinated on day $D$ and $n$ is number of days counted from the beginning of the germination test.

2.1.3. Vigor Index Measurement. Seedling vigor was calculated by following Vashisth and Nagarajan [11].

$$
\begin{aligned}
\text { Vigor index I } & =\text { germination } \% \times \text { seedling length }(\text { root }+ \text { shoot }) \\
\text { Vigor index II } & =\text { germination } \% \times \text { seedling dry weight }(\text { root }+ \text { shoot })
\end{aligned}
$$

Similarly, number of leaves per plant was manually counted of all plants in each row in the field and mean was calculated. Ten plants were used for the estimation of these traits. Shoot length was calculated using measuring tape from the ground to the ligule of upper most leaf of plants of each pot and then average length of each plant/shoot was calculated. At the time of harvest $\left(7^{\text {th }}\right.$ day), the plants were uprooted form land and root length was recorded with the help of scale and average was calculated. Total fresh weight per plant was calculated by adding shoot and root fresh weight of each plant. Plants were shade-dried and total dry weight per plant was calculated based on dry weight of root and shoot.

2.2. Final Field Experiment. Final field experiment with selected dose $\left(3 \% \mathrm{ZnSO}_{4}\right)$ was planned with Randomized
Complete Block Design (RCBD) with three replicates and two harvests (at vegetative stage and final maturity stage). Hydroprimed seeds were used as control. A distance of 2.5 to $3.5 \mathrm{~m}$ was maintained between rows and there was a gap of 90 to $120 \mathrm{~cm}$ between two plants. Experiment was conducted in two consecutive growing seasons under natural field conditions. Presented data is based upon average of both experiments.

2.2.1. Photosynthetic Pigments. Photosynthetic pigments were determined following the method of Bukhari et al. [8]. Fresh leaves $(0.5 \mathrm{~g})$ were ground in $80 \%$ acetone with pestle and mortar. The filtrate was made up to $10 \mathrm{~mL}$ and absorbance was taken at $645 \mathrm{~nm}, 663 \mathrm{~nm}$, and $480 \mathrm{~nm}$ using a spectrophotometer. Estimations for quantity of chlorophylls $a, b$, and total were made by the following formulas: 


$$
\begin{aligned}
\text { Chl.a }\left(\frac{m g}{g}\right) & =[12.7 O D 663-2.69(O D 645)] \times \frac{V}{1000} \times W, \\
\text { Chl.b }\left(\frac{m g}{g}\right) & =[22.9 O D 645-4.68(O D 663)] \times \frac{V}{1000} \times W, \\
\text { Total Chl. }\left(\frac{m g}{g}\right) & =[20.2 O D 645+8.02(O D 663)] \times \frac{V}{1000} \times W,
\end{aligned}
$$

where $V$ is volume of the acetone used and $W$ is weight of leaf used.

2.2.2. Antimicrobial Activity. Using water, acetone, and methanol as solvents, three extractions of fresh leaf sample $(0.1 \mathrm{~g}$ for each extraction) were prepared. Then, antimicrobial activities were measured by Broth Micro Dilution Method [12]. Briefly, the microdilution trays were first prepared using 2-6-fold dilutions of each sample extract volumetrically in broth. A new pipette was used for each subsequent dilution step. The extracts were dispensed into the plastic microdilution trays. The bacterial cultures of $S$. aureus and $P$. aeruginosa were grown in proper growth medium to prepare inoculum and $0.01 \mathrm{~mL}$ of the suspension was inoculated carefully into the broth. The bacterial growth was maintained approximately at $5 \times 105 \mathrm{CFU} / \mathrm{mL}$ (or $5 \times 104 \mathrm{CFU} /$ well in the microdilution method). Using growth method, the standardization of the inoculum was prepared within $15 \mathrm{~min}$. The standardized inoculum was inoculated within $15 \mathrm{~min}$ in each well of a microdilution tray using an inoculator device to deliver a volume that would not exceed $10 \%$ of the volume in the well. Colony counts of inoculum suspensions were done followed by incubation at $35 \pm 2^{\circ} \mathrm{C}$ for 16 to $20 \mathrm{~h}$ in an ambient air incubator. Finally, the lowest concentration of leaf extracts that completely inhibited the bacterial growth in the microdilution wells was detected expressing the minimal inhibitory concentration (MIC).
2.2.3. Catalase Activity. Catalase activity was assayed following the methods described by Bukhari et al. [8] and Sharma [13] with minor modifications. Briefly, $0.5 \mathrm{~g}$ of $M$. charantia samples (each of leaves, peel, and fruit) was taken and homogenized in $1.5 \mathrm{~mL}$ of $1 \mathrm{M}$ phosphate buffer $(\mathrm{pH} 7.0)$ by grinding in a pre-chilled mortar. The homogenate was centrifuged at $15,000 \mathrm{rpm}$ for $15 \mathrm{~min}$ at $40^{\circ} \mathrm{C}$ and supernatant was used for catalase activity analysis. Hydrogen peroxide $\left(\mathrm{H}_{2} \mathrm{O}_{2}\right)$ and phosphate buffer $(3.0 \mathrm{~mL})$ were taken in a cuvette, followed by the rapid addition of $40 \mu \mathrm{L}$ of enzyme extract and mixed thoroughly. The time required for a decrease in absorbance by 0.05 units was recorded at $240 \mathrm{~nm}$ in a spectrophotometer (Genesys 10-S, USA). One enzyme unit was calculated as the amount of enzyme required to decrease the absorbance at $240 \mathrm{~nm}$ by 0.05 units.

2.2.4. Peroxidase Activity. POD was determined by the methods of Bukhari et al. [8] and Bhargavi et al. [14] using $20 \mathrm{~mm}$ guaiacol and $\mathrm{H}_{2} \mathrm{O}_{2}$ as a substrate. Briefly, $0.5 \mathrm{~g}$ of plant material was extracted in $3 \mathrm{~mL}$ of $0.1 \mathrm{M}$ phosphate buffer of pH.7.0 by grinding in a pre-chiller mortar. The homogenate was then centrifuged at $18,000 \mathrm{rpm}$ for $15 \mathrm{~min}$ at $5^{\circ} \mathrm{C}$. Supernatant was used as enzyme source within 2-4 hours, stored on ice till the assay was carried out. Then, $3 \mathrm{~mL}$ of the buffer solution, $0.05 \mathrm{~mL}$ guaiacol solution, $0.1 \mathrm{~mL}$ enzyme extract, and $0.03 \mathrm{~mL}$ hydrogen peroxide $\left(\mathrm{H}_{2} \mathrm{O}_{2}\right)$ solution were pipetted out in a cuvette. The mixture was well shaken and placed in the spectrophotometer. The time required for the mixture to increase absorbance by $0.1(\Delta \mathrm{t})$ at $430 \mathrm{~nm}$ was recorded and used in calculations.

$$
\begin{aligned}
\text { The enzyme specific activity units }\left(g^{-1} f . w t .\right) & =\left[\frac{500}{\Delta t}\right] \times\left[\frac{1}{1000}\right] \times\left[\frac{T V}{V U}\right] \times\left[\frac{1}{f . w t .}\right], \\
\Delta t & =\text { change in time }(\min ), \\
T V & =\text { total volume of } \operatorname{extract}(m L), \\
U V & =\operatorname{volume} \text { used }(m L), \\
f . w t . & =\text { weight of fresh leaf tissues }(g) .
\end{aligned}
$$

2.2.5. Total Soluble Proteins. For total soluble proteins, the method of Bradford [14] was followed with some modifications as described by Bukhari et al. [8]. Briefly, $0.5 \mathrm{~g}$ of
M. charantia sample was homogenized with $1.5 \mathrm{~mL}$ of $1 \mathrm{M}$ phosphate buffer of $\mathrm{pH} 7.0$ by grinding in a pre-chiller mortar. The homogenate was centrifuged at $12,000 \mathrm{rpm}$ for 
$15 \mathrm{~min}$ at $40^{\circ} \mathrm{C}$ and supernatant was used for total soluble protein determination. The spectrophotometer was warmed up before use. First of all, Bradford reagent was prepared by treating $0.1 \mathrm{~g}$ of Coomassie blue dye with $50 \mathrm{~mL}$ of ethanol and $100 \mathrm{~mL}$ of orthophosphoric acid. The total volume was made up to $1,000 \mathrm{~mL}$ and the mixture was filtered carefully. Then, $0.1 \mathrm{~mL}$ of the extract was taken and placed for $15 \mathrm{~min}$ at room temperature for proper reaction. A spectrophotometer was used to measure wavelength at $595 \mathrm{~nm}$ (Jenway, 6700; Thermo Fisher Scientific; USA). Bovine serum albumin was taken as a standard and calculations were made using the standard curve.

2.2.6. Total Free Amino Acids. Total free amino acids were determined following Noreen et al. [15] with some modifications as described previously by Bukhari et al. [8]. Briefly, $0.5 \mathrm{~g}$ of $M$. charantia sample was homogenized with $1.5 \mathrm{~mL}$ of $1 \mathrm{M}$ phosphate buffer ( $\mathrm{pH} 7.0$ ) by grinding in a pre-chiller mortar. The homogenate was centrifuged at $12,000 \mathrm{rpm}$ for $15 \mathrm{~min}$ at $40^{\circ} \mathrm{C}$ and supernatant was used for total free amino acids analysis. The extract $(1 \mathrm{~mL})$ was taken in a test tube and $10 \%$ pyrimidine solution and $1 \mathrm{~mL}$ of $2 \%$ ninhydrin solution (solution was prepared by dissolving $2 \mathrm{~g}$ ninhydrin in $100 \mathrm{~mL}$ dist. water) were added. The test tubes containing the mixture were heated at $100^{\circ} \mathrm{C}$ for $30 \mathrm{~min}$ in a water bath and then mixture (i.e., $2.7 \mathrm{~mL}$ ) was transferred into a $10 \mathrm{~mL}$ volumetric flask. The final volume of the mixture was made up to $10 \mathrm{~mL}$ with distilled water. The optical density of the solution was measured at $570 \mathrm{~nm}$ with the help of a spectrophotometer (Jenway 6700; Thermo Fisher Scientific; USA). Calculations were made using the standard curve prepared with proline.

2.2.7. Total Soluble Sugar. Total soluble sugar was determined by the method defined by Bukhari et al. [8] and Van Handel [16]. Briefly, $0.5 \mathrm{~g}$ of $M$. charantia samples (each of leaves, peel, and fruit) was taken and homogenized in $1.5 \mathrm{~mL}$ of $1 \mathrm{M}$ phosphate buffer ( $\mathrm{pH} 7$ ) by grinding in a pre-chilled mortar. The homogenate was centrifuged at 15,000 rpm for $15 \mathrm{~min}$ at $40^{\circ} \mathrm{C}$ and supernatant was used for total soluble sugar analysis. The extract $(100 \mu \mathrm{L})$ was taken in a test tube and $900 \mu \mathrm{L}$ of dist. $\mathrm{H}_{2} \mathrm{O}$ was added. After that, $3 \mathrm{~mL}$ of anthrone reagent was added and the test tube was incubated in a shaker for $5 \mathrm{~min}$ at $120 \mathrm{rpm}$ and then set in a water bath at $95^{\circ} \mathrm{C}$ for $10 \mathrm{~min}$. The reaction mixture was cooled and absorbance was taken at $625 \mathrm{~nm}$. The amount of soluble sugars in the sample was calculated using glucose standard curve prepared by plotting concentration of the standard on the $X$-axis versus absorbance on the $Y$-axis.

2.2.8. Total Phenolic Contents. Contents of total phenols were determined as reported by Ustaömer et al. [17] using Folin-Ciocalteu reagent method. The dilutions were made to ensure the oxidation of $1 \mathrm{~mL}$ of Folin-Ciocalteu reagent with $200 \mu \mathrm{L}$ of water followed by the neutralization with $2 \mathrm{~mL}$ of $7.5 \%$ sodium carbonate $(\mathrm{w} / \mathrm{v})$. Finally, this volume was made up to $7 \mathrm{~mL}$ with distilled water. The absorbance of the resulting blue color was measured at $765 \mathrm{~nm}$ on spectrophotometer with a $1 \mathrm{~cm}$ cell after incubation for 2 hours in the dark at room temperature. Gallic acid was used as a standard for the calibration curve.

2.2.9. Total Flavonoid Contents. Total flavonoid contents were determined by colorimetric assay [18] with minor modifications. The diluted sample $(1 \mathrm{~mL})$ from the above was added to a $10 \mathrm{~mL}$ volumetric flask containing $4 \mathrm{~mL}$ of distilled water followed by immediate addition of $0.6 \mathrm{~mL}$ of $5 \%$ $\mathrm{NaNO}_{2}, 0.5 \mathrm{~mL}$ of $10 \% \mathrm{AlCl}_{3}$ after $5 \mathrm{~min}$, and $2 \mathrm{~mL}$ of $1 \mathrm{M}$ $\mathrm{NaOH}$ after $1 \mathrm{~min}$. Furthermore, each reaction flask was then immediately diluted with $2.4 \mathrm{~mL}$ of distilled water and mixed. The absorbance of the pink color solution was noted at $510 \mathrm{~nm}$. The quercetin $(\mu \mathrm{g} / \mathrm{g})$ was used as a standard for the calibration curve.

2.2.10. Antiglycation Activity. In $1 \mathrm{~g}$ of sample, $1.5 \mathrm{~mL}$ methanol (50\%) was added and centrifuged at $1500 \mathrm{rpm}$ for $10 \mathrm{~min}$. The supernatant was used for analysis of antiglycation activity. The advanced glycation end-products (AGEs) formation was assessed by characteristic absorbance [19]. Briefly, the reaction mixture of $150 \mu \mathrm{L}$ D-glucose, $150 \mu \mathrm{L}$ bovine serum albumin (BSA in $1 \mathrm{~mL}$ sodium phosphate buffer, $\mathrm{pH} 7.2$ ), and $150 \mu \mathrm{L}$ sample was incubated at room temperature for 7 days. The absorbance was measured using a spectrophotometer at a wavelength of $440 \mathrm{~nm}$. The reaction mixture without D-glucose was used as a blank. Measurements were performed in duplicate.

\subsubsection{Calculation of 50\% Inhibitory Concentration (IC50\%).} The $\mathrm{IC}_{50}$ value is a quantitative measure and used to show how much of a particular inhibitory substance will be required for in vitro inhibition of a specific biological process or component by $50 \%$. The $\%$ inhibition was calculated using the following equation:

$$
\% \text { inhibition }=\frac{\text { absorbance of control }- \text { absorbance of sample }}{\text { absorbance of control }} \times 100 \text {. }
$$

2.2.12. Quantitative Analysis of Phenolic Profile through HPLC. HPLC was done for the investigation of individual phenolic profile following the procedure reported by Hussain et al. [20] with slight modifications previously described by Bukhari et al. [8]. Leaves and fruit samples (i.e., $1 \mathrm{~g}$ of each) of $M$. charantia were preserved in liquid nitrogen and $0.5 \mathrm{~g}$ of each sample was taken and homogenized with $1.5 \mathrm{~mL}$ of HPLC grade three extraction solvent combinations 
$\left(80: 20 \mathrm{v} / \mathrm{v}\right.$ ethanol: $\mathrm{H}_{2} \mathrm{O}, 70: 25: 0.5 \mathrm{v} / \mathrm{v} / \mathrm{v}$ methanol: $\mathrm{H}_{2} \mathrm{O}$ : $\mathrm{HCl}$, and $50: 50 \mathrm{v} / \mathrm{v}$ dimethyl sulfoxide (DMSO):methanol). Freeze-dried homogenate was centrifuged at $18,000 \mathrm{rpm}$ for $15 \mathrm{~min}$ at $4^{\circ} \mathrm{C}$ and supernatant was used for HPLC analysis. Varian HPLC using ODS $\left(\mathrm{C}_{18}\right)$ reversed phase column was used for the identification of phenolic acids present in extracts. To separate different phenolic acids, two solvents (i.e., solvent 1 , acetonitrile (70): methanol (30) and solvent 2, $0.5 \%$ glacial acetic acid) were used as mobile phase with a constant flow rate of $1 \mathrm{~mL} / \mathrm{min}$ in gradient mode. Microsyringe was used to inject the sample in the column and volume of sample injected was $20 \mu \mathrm{L}$. Detection was carried out at $275 \mathrm{~nm}$. Identification of phenolic acids was performed by correlating their relative retention times with those of standard mixture chromatogram. The amounts of individual compounds were measured based on peak area measurement.

2.3. Statistical Analysis. MS Excel was used for graphical presentation of the data. All determinations were made in complete randomized designs. The presence or absence of significant difference among different factors was as curtained with the analysis of variances (ANOVA). The means were compared with least significant difference (LSD) at the level of significance of 0.05 . Overall interaction of all the factors was checked for significance using computer software CoStat CoHort (6.4).

\section{Results}

\subsection{Pilot Experiment}

3.1.1. Percentage of Final Emergence Rate. It was found that the final emergence percentage rate of $M$. charantia seeds treated with $0.3 \%$ of zinc sulfate solution had a higher percentage of emergence as compared to $0.1 \%$ and $0.2 \%$ solutions (Figure 1(a)). Moreover, it was also found that control group with hydropriming had higher final emergence rate (i.e., $22 \%$ ) as compared to unprimed (18\%). Therefore, a positive correlation for final emergence rate was observed between zinc sulfate treated and water treated plants and the percentage of final emergence rate in zinc sulfate treated seeds of $M$. charantia was significant $(p<0.05)$ as compared to untreated samples.

3.1.2. Emergence Index. It was found that $0.3 \%$ zinc sulfate solution has higher emergence index that was comparable with the control groups (Figure 1(b)), so that emergence index in zinc sulfate treated $M$. charantia seeds was significant $(p \leq 0.05)$ as compared to untreated samples.

3.1.3. Vigor Indices I and II. The vigor indices I and II in zinc sulfate treated $M$. charantia seeds were significant $(p \leq 0.05)$ as compared to untreated samples (Figures $1(\mathrm{c})$ and $1(\mathrm{~d})$ ).

\subsection{Growth Attributes}

3.2.1. Root Length and Shoot Length. Statistical analysis of plant root length and shoot length revealed a significant effect of treatment according to the analysis of variance data $(p \leq 0.05)$. In plants treated with zinc, root length remained unaffected as compared to untreated plants (Figure 2(a)), while shoot length of zinc-treated plants was improved as compared to control plants (Figure 2(b)).

3.2.2. Root Fresh Weight and Shoot Fresh Weight. The root fresh weight indicated nonsignificant results $(p \leq 0.05)$ of the treatment in plants (Figure 2(c)) whereas shoot fresh weight showed highly significant effect of treatment according to the analysis of variance data $(p \leq 0.05)$. Plants treated with zinc showed higher shoot fresh biomass as compared to control plants (Figure 2(d)).

3.2.3. Leaf Fresh Weight and Leaf Area. Results of statistical analysis of leaf fresh weight indicated highly significant effect of treatment according to variance data $(p \leq 0.05)$. Plants treated with zinc had leaf fresh weight greatly increased as compared to control plant (Figure 2(e)) whereas leaf area by statistical analysis represented non-significance $(p \leq 0.05)$ for the treatment (Figure 2(f)).

3.2.4. Number of Flowers and Fruit Weight. Statistical analysis of fruit weight indicated nonsignificant effects $(p \leq 0.05)$ of treatment (Figure $2(\mathrm{~g}))$ whereas number of flowers indicated highly significant effects of treatment according to the variance data $(p \leq 0.05)$. The number of flowers was increased in the plants treated with zinc as compared to the untreated plants (Figure 2(h)).

The data presented is the mean of three replicates. Values are mentioned as mean $( \pm S D)$. Treatments with significant differences $(p \leq 0.05)$ are mentioned as ' $a$ ' and ' $b$ '.

3.2.5. Germination \%Age. Statistical analysis of germination percentage revealed significant effect $(p \leq 0.05)$ of the treatment as zinc sulfate treated plants had shown higher germination percentage $(55.76 \pm 5.72)$ as compared to control plants $(26.67 \pm 5.77)$.

\subsection{Field Experiment}

3.3.1. Total Soluble Sugar and Protein. Results of statistical analysis of total soluble sugar expressed nonsignificant effects $(p \leq 0.05)$ of treatments in leaves (Table 1) and whole fruit (Table 2). However, there was a decline in peel (Table 2). Protein in leaves had a significant effect of treatment according to the variance data $(p \leq 0.05)$. Plants treated with zinc had reduced protein in leaves as compared to control plants (Table 1) whereas in fruit it showed marked increase and in peel it was with insignificant difference (Table 2). 


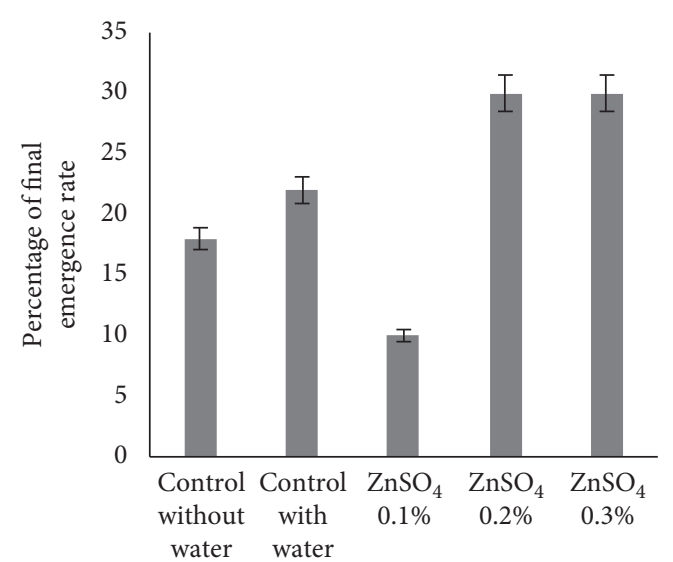

(a)

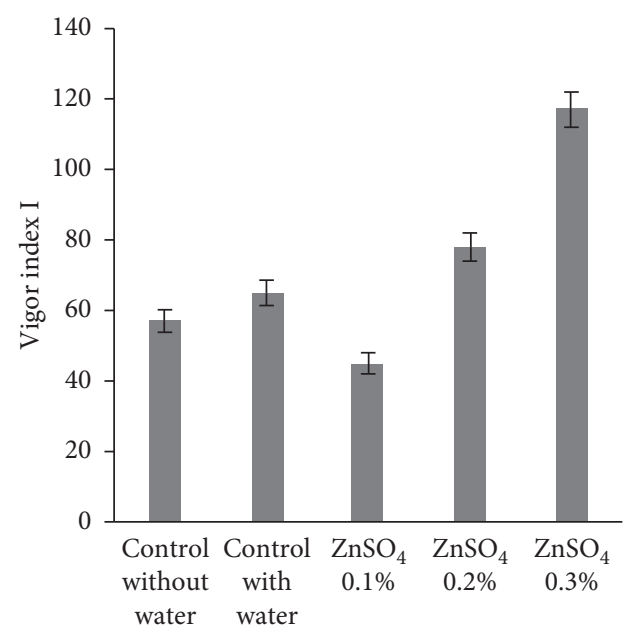

(c)

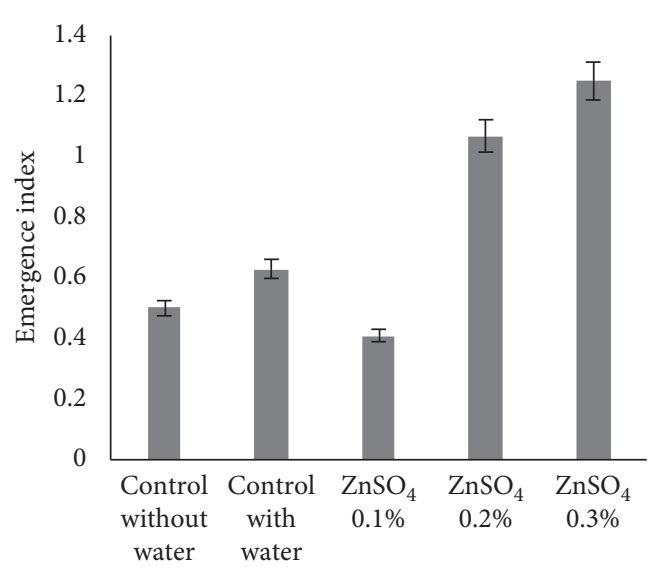

(b)

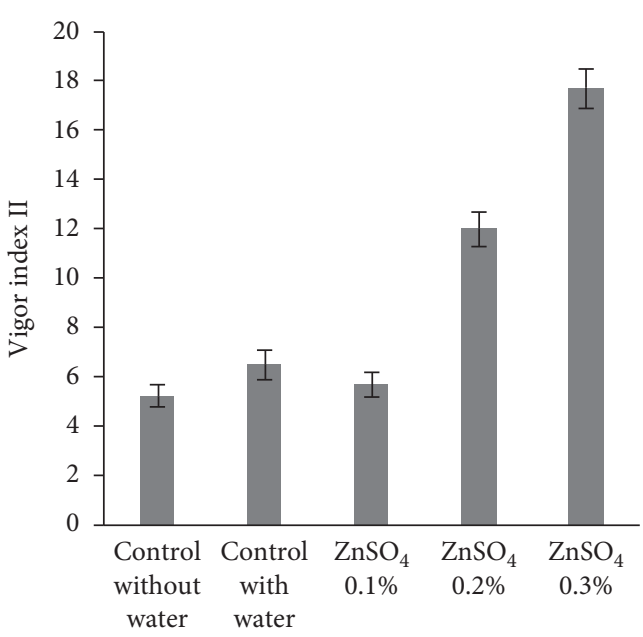

(d)

Figure 1: Optimization of zinc sulfate level as priming agent for M. charantia in terms of seedling establishment.

3.3.2. Phenolic and Flavonoid Contents. Plant phenolic and flavonoid contents in leaves revealed significant results of treatment according to analysis of variance data $(p \leq 0.05)$. Plants treated with zinc sulfate had a gradual decrease in these secondary metabolites (Table 1).

3.3.3. Free Amino Acids. Free amino acids revealed nonsignificant results of treatment according to analysis of variance data $(p \leq 0.05)$. Plants treated with zinc sulfate had a gradual increase in free amino acids of fruit peel (Table 2) whereas it was nonsignificant for other two parts (Table 1).

3.3.4. Photosynthetic Pigments. Statistical analysis of plant chlorophyll-a and chlorophyll-b and total chlorophyll in leaves indicated significant effects $(p \leq 0.05)$ of the treatment as their levels were increased as compared to those of control plants (Table 1).

The data presented is the mean of three replicates. Values are mentioned as mean $( \pm S D)$. Treatments with significant difference $(p \leq 0.05)$ are mentioned as 'a' and 'b'.
3.3.5. Antiglycation. Zinc sulfate treatment on seeds of $M$. charantia has no effect on the antiglycation level in its fruits.

3.3.6. Phenolic Profile. Freeze-dried samples (leaf, fruit) of $M$. charantia showed significant difference between zinc sulfate treated and untreated plants (i.e., represented by analysis of variance). In leaves, the concentrations of quercetin and cinnamic acid were decreased after zinc sulfate treatment (Figure 3). In fruits, the concentration of quercetin was decreased after zinc sulfate treatment while concentrations of caffeic acid and syringic acid were found to be $8.64 \mathrm{ppm}$ and $3.77 \mathrm{ppm}$, respectively, and both phenolics were not detected in control $M$. charantia plants (Figure 4). Fruit phenolics (Table 3) showed a significant correlation with metabolizable energy (the physiologically useful energy obtained when protein, fat, or carbohydrate is catabolized), peroxidase, and free amino acids while they showed a nonsignificant correlation with nutritive parameters. The HPLC chromatogram of phenolic profile of standards is shown in Fig. S1. 


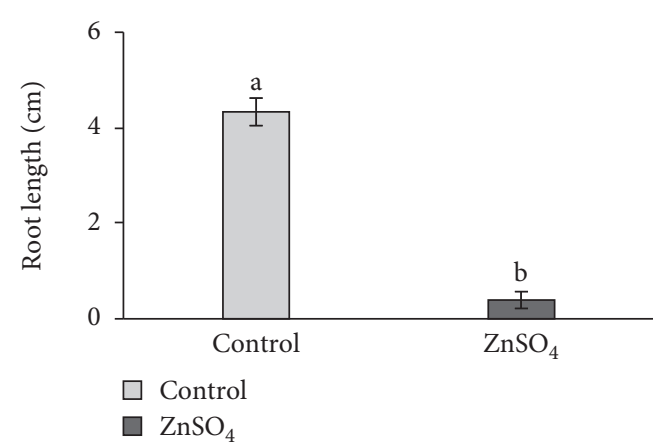

(a)

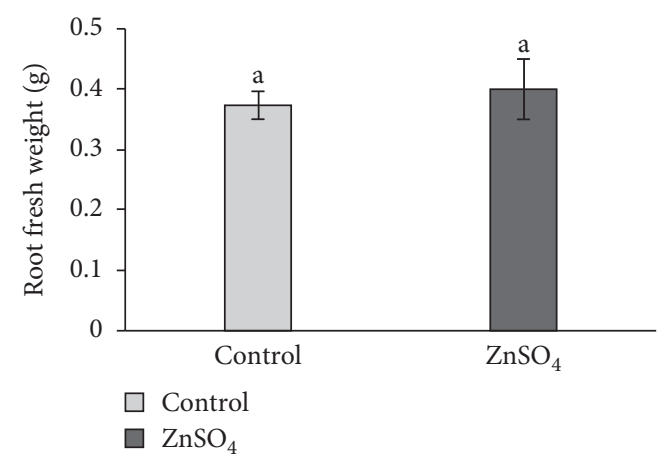

(c)

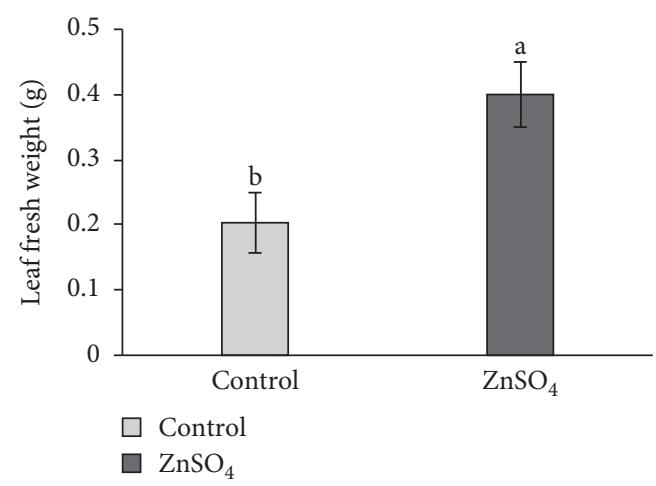

(e)

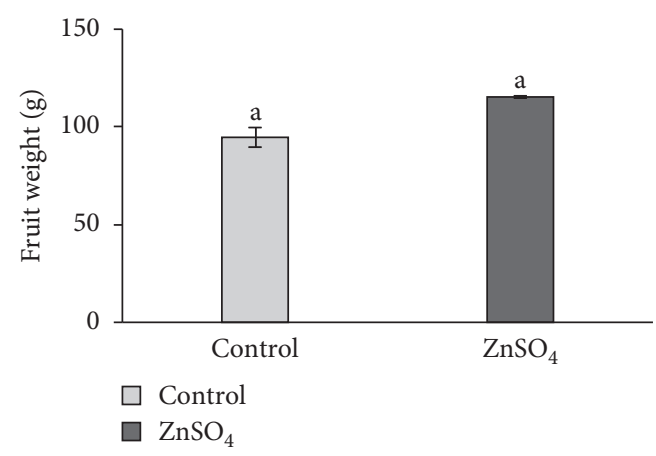

(g)

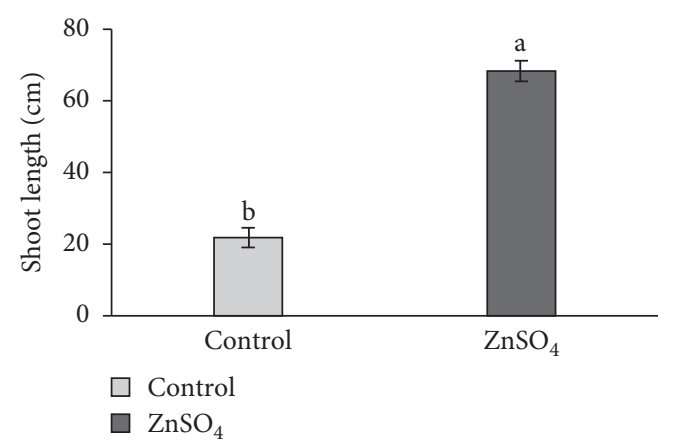

(b)

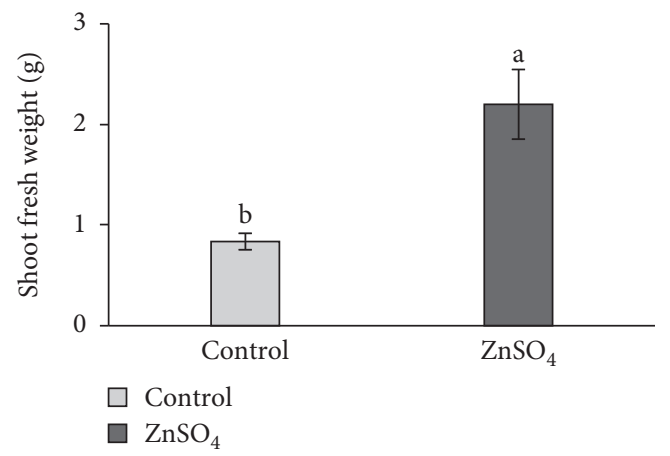

(d)

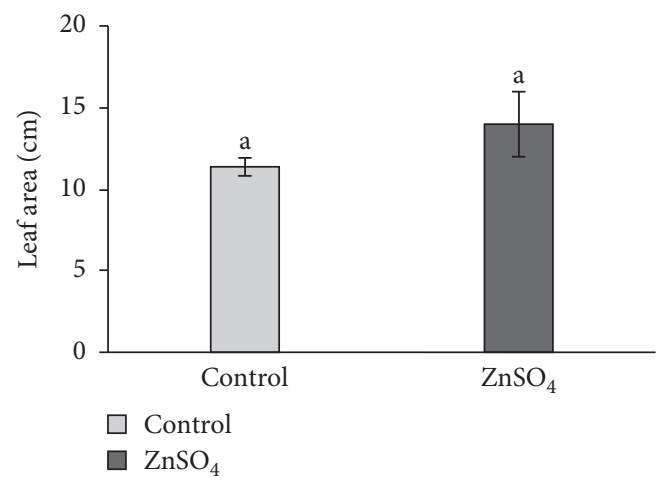

(f)

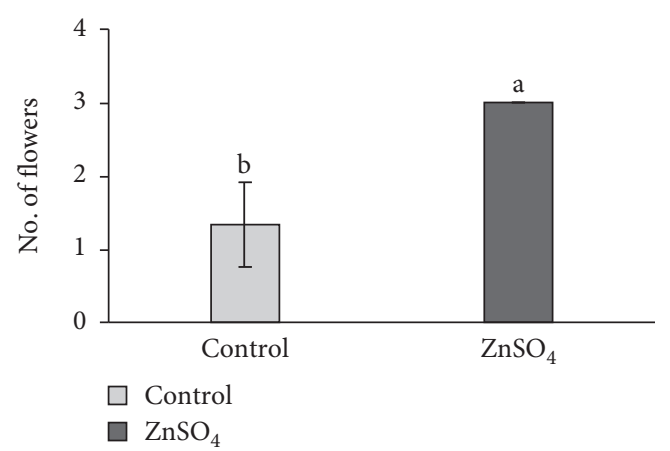

(h)

Figure 2: Effect of zinc sulfate seeds priming upon morphological parameters of (M) charantia. (a) Root length, (b) shoot length, (c) root fresh weight, (d) shoot fresh weight, (e) leaf fresh weight, (f) leaf area, (g) fruit weight, (h) no. of flowers.

3.3.7. Antimicrobial Activity. At the vegetative growth stage, non-treated leaf extracts exhibited better activity in methanol extract followed by acetone and water. Zinc sulfate treatment improved antimicrobial activity in each extraction against $P$. aeruginosa but only in methanol extraction against S. aureus (Figure 5). Both bacterial species showed positive 
TABLE 1: Biochemical analysis of zinc sulfate treatment on seed priming of $M$. charantia at biochemical attributes of vegetative tissues in leaves.

\begin{tabular}{|c|c|c|}
\hline Biochemical analysis & Control M. charantia & Treated M. charantia \\
\hline Total soluble sugar (\%) & $28.43 \pm 3.11^{\mathrm{a}}$ & $30.54 \pm 2.26^{\mathrm{a}}$ \\
\hline Protein $(\mathrm{mg} / \mathrm{g})$ & $27.4 \pm 1.162^{\mathrm{a}}$ & $20.16 \pm 0.04^{b}$ \\
\hline Phenolic content $(\mathrm{mg} / \mathrm{g})$ & $10.21 \pm 0.01^{\mathrm{a}}$ & $4.76 \pm 0.02^{\mathrm{b}}$ \\
\hline Free amino acids (mg/g) & $4.07 \pm 0.06^{\mathrm{a}}$ & $3.6 \pm 0.36^{\mathrm{a}}$ \\
\hline Chlorophyll-a (mg/g) & $2.85 \pm 0.01^{b}$ & $6.34 \pm 0.58^{\mathrm{a}}$ \\
\hline Chlorophyll-b (mg/g) & $3.78 \pm 0.66^{\mathrm{b}}$ & $7.33 \pm 0.68^{\mathrm{a}}$ \\
\hline Flavonoid $(\mathrm{mg} / \mathrm{g})$ & $6.86 \pm 0.01^{\mathrm{a}}$ & $3.07 \pm 0.06^{\mathrm{b}}$ \\
\hline Total chlorophyll content $(\mathrm{mg} / \mathrm{g})$ & $7.16 \pm 1.03^{\mathrm{b}}$ & $17.67 \pm 0.58^{\mathrm{a}}$ \\
\hline Catalase (U/g) & $542.4 \pm 17.86^{\mathrm{a}}$ & $466.87 \pm 57.39^{\mathrm{a}}$ \\
\hline Peroxidase (U/g) & $5.68 \pm 0.01^{\mathrm{a}}$ & $6.44 \pm 0.33^{\mathrm{a}}$ \\
\hline Carotenoids $(\mu \mathrm{g} / \mathrm{g})$ & $5.03 \pm 0.06^{\mathrm{a}}$ & $3.28 \pm 0.49^{\mathrm{a}}$ \\
\hline Anthocyanin $(\mathrm{mg} / \mathrm{g})$ & $0.66 \pm 0.002^{\mathrm{a}}$ & $0.54 \pm 0.001^{\mathrm{a}}$ \\
\hline
\end{tabular}

TABLE 2: Biochemical attributes of zinc sulfate treatment on seed priming of $M$. charantia for nutritive analysis in fruit and peel.

\begin{tabular}{|c|c|c|c|c|}
\hline \multirow[b]{2}{*}{ Proximate analysis } & \multicolumn{2}{|c|}{ Fruit } & \multicolumn{2}{|c|}{ Peel } \\
\hline & Control & Treated & Control & Treated \\
\hline Free amino acid $(\mathrm{mg} / \mathrm{g})$ & $10.44 \pm 0.05^{\mathrm{a}}$ & $8.43 \pm 0.02^{\mathrm{a}}$ & $0.5 \pm 1.05^{\mathrm{b}}$ & $1.96 \pm 0.31^{\mathrm{a}}$ \\
\hline Crude fiber (\%) & $3.08 \pm 0.04^{\mathrm{a}}$ & $2.81 \pm 0.02^{\mathrm{a}}$ & $3.4 \pm 0.44^{\mathrm{a}}$ & $3.62 \pm 0.10^{\mathrm{a}}$ \\
\hline Protein $(\mathrm{mg} / \mathrm{g})$ & $26.62 \pm 1.57^{\mathrm{b}}$ & $76.20 \pm 3.56^{\mathrm{a}}$ & $26.78 \pm 0.68^{\mathrm{a}}$ & $28.63 \pm 0.15^{\mathrm{a}}$ \\
\hline Total soluble sugar (\%) & $39 \pm 3.46^{\mathrm{a}}$ & $40.53 \pm 1.65^{\mathrm{a}}$ & $31.6 \pm 0.07^{\mathrm{a}}$ & $30.05 \pm 0.2^{\mathrm{b}}$ \\
\hline Ash (\%) & $14.93 \pm 0.46^{\mathrm{a}}$ & $20.53 \pm 2.57^{\mathrm{b}}$ & $15.82 \pm 0.75^{\mathrm{a}}$ & $15.38 \pm 0.75^{\mathrm{a}}$ \\
\hline Peroxidase (U/g) & $2.24 \pm 0.41^{\mathrm{a}}$ & $3.04 \pm 0.56^{\mathrm{a}}$ & $2.43 \pm 0.57^{\mathrm{b}}$ & $5.64 \pm 0.25^{\mathrm{a}}$ \\
\hline Catalase $(\mathrm{U} / \mathrm{g})$ & $322.9 \pm 48.52^{\mathrm{a}}$ & $347.47 \pm 34.76^{\mathrm{a}}$ & $374.3 \pm 17.31^{\mathrm{a}}$ & $290.13 \pm 4.69^{\mathrm{a}}$ \\
\hline Oil (\%) & $0.96 \pm 0.01^{\mathrm{a}}$ & $0.96 \pm 0.01^{\mathrm{a}}$ & $0.97 \pm 0.01^{\mathrm{a}}$ & $0.96 \pm 0.01^{\mathrm{a}}$ \\
\hline Metabolize energy $(\mathrm{kcal} / 100 \mathrm{~g})$ & $17.05 \pm 0.77^{\mathrm{b}}$ & $30.94 \pm 0.86^{\mathrm{a}}$ & $17.05 \pm 0.77^{\mathrm{b}}$ & $28.94 \pm 0.86^{\mathrm{a}}$ \\
\hline
\end{tabular}

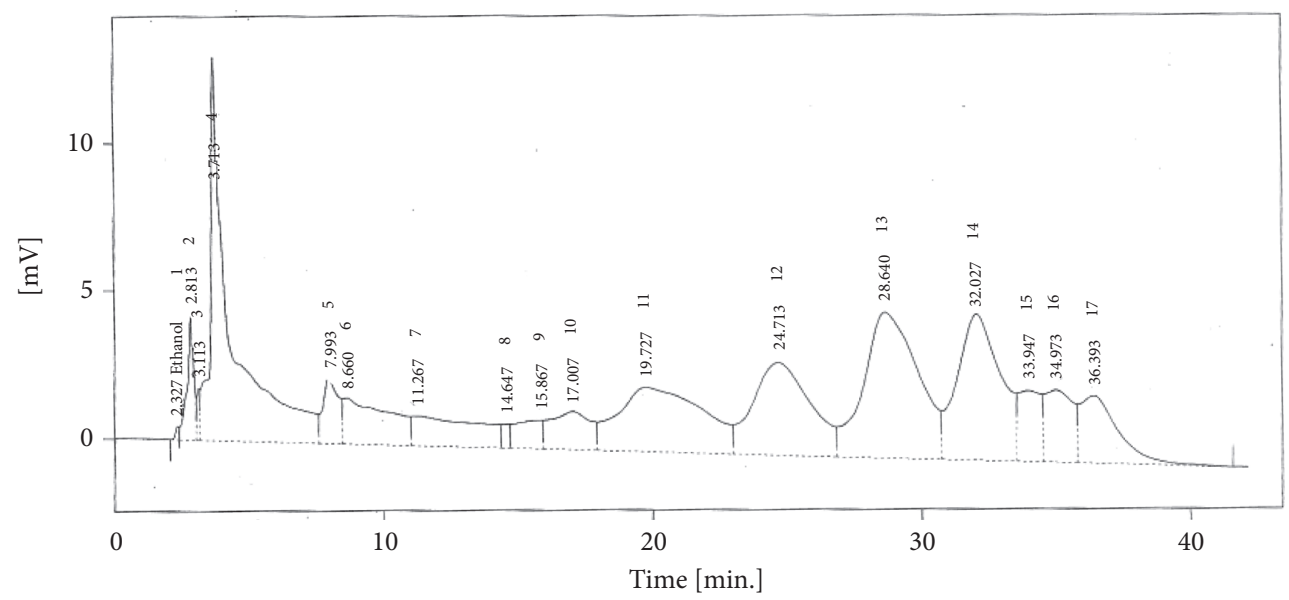

(a)

Figure 3: Continued. 


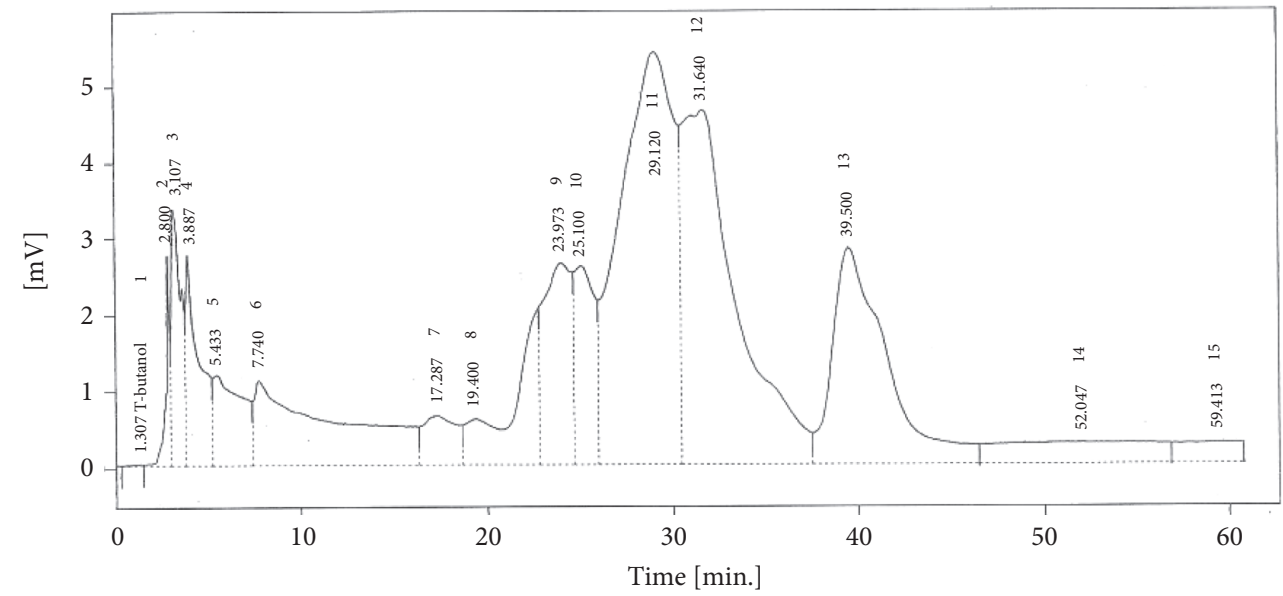

(b)

Figure 3: HPLC chromatograms of (M) charantia (L) leaves for phenolic profile. (a) Control, (b) zinc sulfate priming.

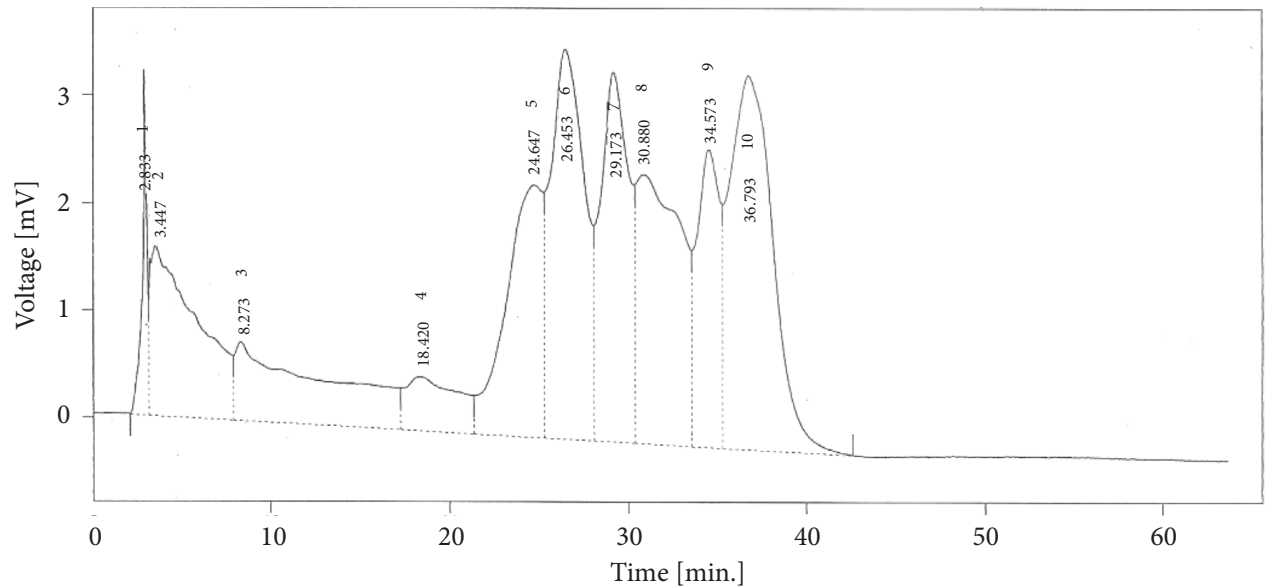

(a)

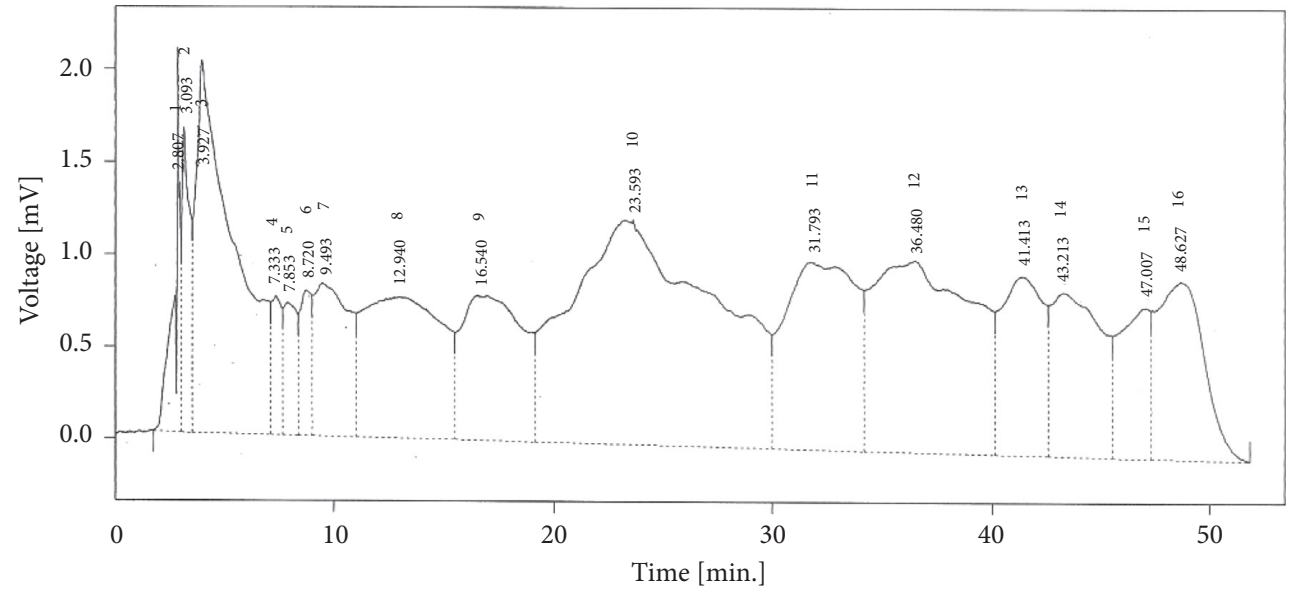

(b)

FIGURE 4: HPLC chromatograms of (M) charantia (L) fruit for phenolic profile. (a) Control, (b) zinc sulfate priming. 
TABle 3: Correlation matrix of leaf antimicrobial activity with enzymes, and primary and secondary metabolites of $M$. charantia.

\begin{tabular}{|c|c|c|c|c|c|c|c|c|c|c|}
\hline \multirow[b]{2}{*}{ Pathogen } & \multicolumn{2}{|c|}{ Enzymes } & \multicolumn{6}{|c|}{ Primary metabolites } & \multicolumn{2}{|c|}{ Secondary metabolites } \\
\hline & Catalase & Peroxidase & Chl-a & Chl-b & Chl-tot & Proteins & Soluble sugar & $\begin{array}{l}\text { Amino } \\
\text { acids }\end{array}$ & Carotenoid & Anthocyanin \\
\hline P. aeruginosa & ns & ns & ns & ns & ns & ns & ns & ns & ns & ns \\
\hline S. aureus & ns & $0.7^{* * *}$ & ns & ns & ns & ns & ns & ns & ns & ns \\
\hline Pathogen & Flavonoid & $\begin{array}{l}\text { Sinapic } \\
\text { acid }\end{array}$ & $\begin{array}{c}\text { Vanillic } \\
\text { acid }\end{array}$ & $\begin{array}{c}\text { Cinnamic } \\
\text { acid }\end{array}$ & $\begin{array}{c}\text { Secondar } \\
\text { Coumaric } \\
\text { acid } \\
\end{array}$ & $\begin{array}{l}\text { metaboli } \\
\text { Syringic } \\
\text { acid }\end{array}$ & $\begin{array}{l}\text { Chlos } \\
\text { acid } \\
\text { Chenic }\end{array}$ & $\begin{array}{c}\text { Benzoic } \\
\text { acid }\end{array}$ & Quercetin & Ferulic acid \\
\hline P. aeruginosa & ns & $1^{* * *}$ & $1^{* * *}$ & $1^{* * *}$ & $0.5^{*}$ & $1^{* * *}$ & $1^{* * *}$ & $1^{* * *}$ & ns & $1^{* * *}$ \\
\hline S. aureus & ns & $1^{* * *}$ & $1^{* * *}$ & $1^{* * *}$ & $1^{* * *}$ & $1^{* * *}$ & $1^{* * *}$ & $1^{* * *}$ & ns & $1^{* * *}$ \\
\hline
\end{tabular}

ns: non-significance at $p<0.05$ and stearic. The symbols ${ }^{*},{ }^{* *}$, and ${ }^{* * *}$ indicate significant correlation.
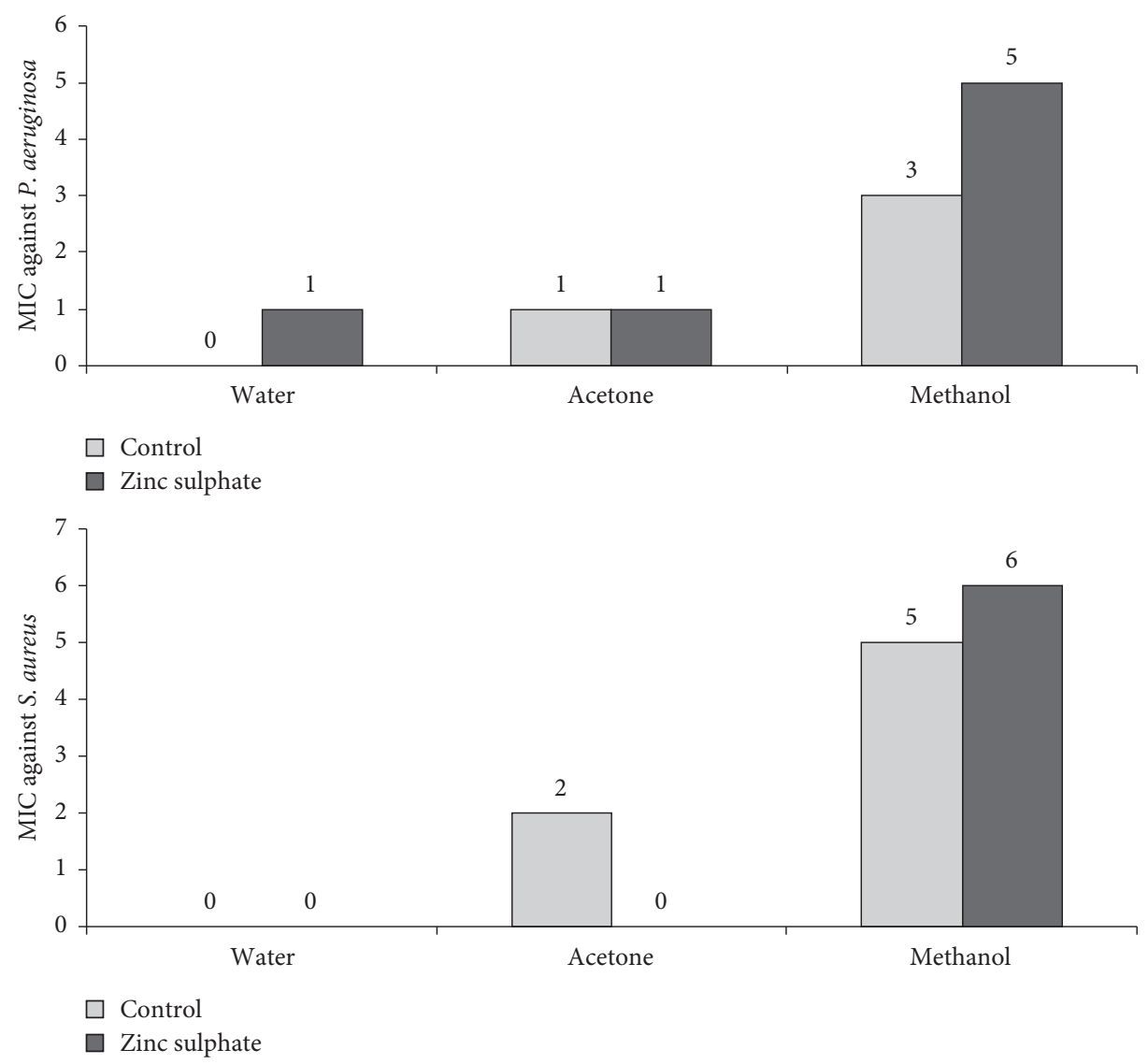

Figure 5: Antimicrobial activity of leaves extractions of (M) charantia against (P) aeruginosa (above) and (S) aureus (below) expressed as minimum inhibitor concentration to inhibit growth of bacterial species.

correlations to peroxidase, sinapic acid, vanillic acid, coumaric acid, syringic acid, chlorogenic acid, benzoic acid, and ferulic acid (Table 3). Both bacterial species revealed a nonsignificant correlation with catalase, chlorophyll-a, chlorophyll-b, total chlorophyll content, proteins, soluble sugar, amino acids, carotenoids, anthocyanin, flavonoid, and quercetin (Table 3).

Results of correlation among fruit phenolics with nutritive parameters of $M$. charantia are given in Table 4 . The ferulic acid and coumaric acid in zinc treated fruit of $M$. charantia showed a direct correlation to metabolizable energy, peroxidase, and free amino acids while an indirect correlation to catalase, soluble sugar, and proteins. Benzoic acid, quercetin, and phenolic acid directly correlated to catalase and soluble sugar and indirectly correlated to metabolizable energy (i.e., the physiologically useful energy obtained when protein, fat, or carbohydrate is catabolized), peroxidase, protein, and amino acids. Sinapic acid and 
TABLE 4: Correlation matrix of fruit phenolics with nutritive parameters of $M$. charantia.

\begin{tabular}{lccccccccc}
\hline Acids & Metabolizable energy & Catalase & Peroxidase & Ash & Soluble sugar & Protein & Crude fiber & Oil & Amino acid \\
\hline Ferulic acid & $0.98^{* * *}$ & $-0.97^{* *}$ & $0.97^{* * *}$ & $\mathrm{~ns}$ & $-0.93^{* *}$ & $-0.91^{* *}$ & $\mathrm{~ns}$ & $\mathrm{~ns}$ & $0.9^{* * *}$ \\
Coumaric acid & $0.98^{* * *}$ & $-0.97^{* *}$ & $0.97^{* * *}$ & $\mathrm{~ns}$ & $-0.93^{* *}$ & $-0.91^{* *}$ & $\mathrm{~ns}$ & $\mathrm{~ns}$ & $0.9^{* * *}$ \\
Benzoic acid & $-0.98^{* * *}$ & $0.97^{* *}$ & $-0.97^{* * *}$ & $\mathrm{~ns}$ & $0.93^{* *}$ & $-0.91^{* *}$ & $\mathrm{~ns}$ & $\mathrm{~ns}$ & $-0.9^{* * *}$ \\
Sinapic acid & $0.98^{* * *}$ & $-0.97^{* *}$ & $0.97^{* * *}$ & $\mathrm{~ns}$ & $-0.93^{* *}$ & $0.91^{* *}$ & $\mathrm{~ns}$ & $\mathrm{~ns}$ & $0.9^{* * *}$ \\
Cinnamic acid & $0.98^{* * *}$ & $-0.97^{* *}$ & $0.97^{* * *}$ & $\mathrm{~ns}$ & $-0.93^{* *}$ & $0.91^{* *}$ & $\mathrm{~ns}$ & $\mathrm{~ns}$ & $0.9^{* * *}$ \\
Quercetin & $-0.98^{* * *}$ & $0.97^{* *}$ & $-0.97^{* * *}$ & $\mathrm{~ns}$ & $0.93^{* *}$ & $-0.91^{* *}$ & $\mathrm{~ns}$ & $\mathrm{~ns}$ & $-0.9^{* * *}$ \\
Phenolic acid & $-0.98^{* * *}$ & $0.97^{* *}$ & $-0.97^{* * *}$ & $\mathrm{~ns}$ & $0.93^{* *}$ & $-0.91^{*}$ & $\mathrm{~ns}$ & $\mathrm{~ns}$ & $-0.9^{* * *}$ \\
\hline
\end{tabular}

ns: non-significance at $p<0.05$. Thee symbols ${ }^{*},{ }^{* *}$, and ${ }^{* * *}$ indicate significant correlation.

cinnamic acid were directly correlated to metabolizable energy, peroxidase, proteins, and amino acids while they were indirectly correlated to catalase and soluble sugars.

\section{Discussion}

$\mathrm{Zn}$ priming in the form of halopriming [21] and nanoparticle [5] has been reported with positive outcomes in a number of crops including wheat [22] and maize [23]. Currently, zinc sulfate priming has showed its potential to effect upon growth and metabolism of $M$. charantia.

In this study, increase in percentage of final emergence rate, emergence index, vigor indices I and II, shoot length, shoot fresh weight, leaf fresh weight, and number of flowers was observed. These findings are in line with Rouhi et al.[24]. Zinc induced betterment of growth, yield, and seedling establishment could be justified by the role of zinc in enzymatic activities associated with auxin metabolism. Zinc plays a crucial role in the efficiency of growth regulation as a structural component and cofactor [25]. Mallikarjuna et al. [26] have given molecular evidences about direct correlation of zinc availability of plants with regulation of ethylene, auxin, gibberellins, and cytokinin like growth regulators hence implying the role in growth and development of plants as depicted by current findings.

Photosynthesis is related to shoot biomass and it varies with the provision of zinc. The limited zinc availability may cause structural damage on photosynthetic, particularly, bundle sheath cells and chloroplast structure. It is related to the possible inhibition of the gene expression responsible for chlorophyll biosynthesis. Additionally, the genes responsible for thylakoid structural organization are noted to be downregulated in case of limited zinc supply hence indicating role of zinc provision to photosynthesis. The correlation of photosynthetic rate and zinc supply is in line with our work [27]. Here, we have noted enhanced chlorophyll-a and total chlorophyll. Photosynthetic pigments have a vital role in biological metabolism ranging from their effects upon plants to the metabolism of consumers. For years, chlorophyll-a to chlorophyll-b ratio and total chlorophyll content were considered as an index for the betterment of plants and their consumers [28]. There was a substantial enhancement of chlorophyll-a, chlorophyll-b, and total chlorophyll contents in zinc sulfate primed $M$. charantia leaves samples. Better photosynthetic activity is always found related to better yield [29].
In the present study, though the fruit weight remained ineffective by zinc sulfate priming, however positive effect of priming upon number of flowers indicated that individual fruit weight even being the same may affect total yield in response to improved chlorophyll contents. Previously, both the positive and negative effects of zinc sulfate seed treatments have been reported which were varied with treatment doses and crop species. It has been suggested that zinc sulfate priming could change free radical or ionic oscillations and movements and improve levels of photosynthetic pigments along with some other metabolic variations [30].

Similarly, seed priming of Phaseolus vulgaris (L.) with zinc improved the yield significantly [31]. Ahmad et al. [32] discussed that seed priming with novel synthetic zinc fertilizers such as $\left[\mathrm{Zn}(\mathrm{Arg})_{2}\right]$ and $\left[\mathrm{Zn}(\mathrm{His})_{2}\right]$ could be more suitable alternatives in relation to commercial applications of zinc sulfate in the soil. The seed priming with zinc is an affordable and practical way for increasing zinc amount in seeds before their sowing which benefits seedling growth and plants show enhanced yield and biomass [33]. Pengel and Graham [34] showed that zinc contents when increased from $0.25 \mu \mathrm{g}$ to $0.70 \mu \mathrm{g}$ per seed significantly improved the growth of root and shoot and therefore it could be concluded that high contents of zinc in seeds could act as starter fertilizer.

Formerly, in a number of studies, zinc application has proved its importance with reference to protein contents in wheat [35] and mungbean [36] where dose-dependent effect of zinc was noted upon crude protein. They observed that zinc deficiency affects nitrogen metabolism in the corn plant. In contrast, Sagardoy et al. [37] observed the antagonistic effect of zinc along with nitrogen in the sugar beet (Beta vulgaris L.) hydroponically grown. In the current study, $M$. charantia manifested marked enhancement in whole fruit of plant grown from zinc-primed seeds. Recent proteomic studies related such zinc based changes in protein with the possible role of zinc in chlorophyll production and related membranous structures [27].

Plant phenolics are one of the blessings for herbal consumers. Phenolics with their nutraceutical role in human being and stress tolerance in plants have made their eminent position in literature. Gąsecka et al. [38] found variable pattern of phenolics in zinc treated plants. They noted enhancement of syringic acid, ferulic acid, p-coumaric acid, caffeic acid, t-cinnamic acid, vanillic acid, and naringenin. Our findings partially agree with them where primed plants showed enhanced accumulation of syringic acid, sinapic 
acid, vanillic acid, ferulic acid, coumaric acid, and benzoic acid contents in $M$. charantia leaves. In the same way, reduction of some phenolics (i.e., quercetin and cinnamic acid) in M. charantia leaves indicated that zinc has some metabolic link with phenylpropanoid pathway responsible to upregulation and downregulation of some genes associated with the above-mentioned phenolics. It indicates that the effect of zinc in modulation of phenolic metabolism varies from species to species. Positive correlation of phenolics with antimicrobial activities against $P$. aeruginosa and $S$. aureus has confirmed the enhanced nutraceutical value of treated plants. Positive correlation of phenolics with antimicrobial activity is in accordance with previous literature. As the zinc priming showed its potential to enhance phenolics content, hence it can be related to the findings of Afonso et al. [39] as scientific justification.

\section{Conclusion}

Products of phenylpropanoid pathway are enhanced with zinc priming of $M$. charantia that improved pharmaceutically important phenolics (e.g., syringic acid, sinapic acid vanillic acid, ferulic acid, coumaric acid, and benzoic acid). Additionally, zinc treated plants were found with better seedling establishment, photosynthetic pigments, and stable nutritive value and therefore proving it as a beneficial fertilizer for $M$. charantia plant growth, yield, and nutraceutical potential.

\section{Data Availability}

The data used to support the findings of this study are available from the corresponding author upon request.

\section{Conflicts of Interest}

The authors declare that they have no conflicts of interest.

\section{Acknowledgments}

The authors are deeply thankful to Ms. Nighat Zia ud Den, $\mathrm{PhD}$ scholar and Researcher from Biochemistry Department of Government College University Faisalabad, Pakistan, for her guidance and Higher Education Commission Islamabad, Government of Pakistan, for support and assistance.

\section{Supplementary Materials}

Figure S1: HPLC chromatograms of phenolic profile of standards. (Supplementary Materials)

\section{References}

[1] M. Farooq, A. Rehman, A. K. M. Al-Alawi, W. M. Al-Busaidi, and D.-J. Lee, "Integrated use of seed priming and biochar improves salt tolerance in cowpea," Scientia Horticulturae, vol. 272, Article ID 109507, 2020.

[2] A. Sen and J. T. Puthur, "Influence of different seed priming techniques on oxidative and antioxidative responses during the germination of Oryza sativa varieties," Physiology and Molecular Biology of Plants, vol. 26, pp. 1-15, 2020.
[3] A. Beenish, A. Muhammad, M. Saqib, W. Abdul, and P. Abida, "Improved growth and metabolism of sunflower via physical seed pretreatments," International Journal of Agriculture and Biology, vol. 22, no. 6, pp. 1483-1490, 2019.

[4] P. Dwivedi, D. Amin, and A. Sharma, "Effect of differential concentration of micronutrient copper and zinc on in vitro morphogenesis of Foeniculum vulgare Mill," Plant Physiology Reports, vol. 25, no. 1, pp. 178-184, 2020.

[5] J. I. García-López, G. Niño-Medina, E. Olivares-Sáenz et al., "Foliar application of zinc oxide nanoparticles and zinc sulfate boosts the content of bioactive compounds in habanero peppers," Plants, vol. 8, no. 8, p. 254, 2019.

[6] R. Sathasivam, C. H. Park, H. J. Yeo, Y. E. Park, J. K. Kim, and S. U. Park, "Analysis of triterpenoids, carotenoids, and phenylpropanoids in the flowers, leaves, roots, and stems of white bitter melon (Cucurbitaceae, Momordica charantia)," Tropical Journal of Pharmaceutical Research, vol. 20, no. 1, pp. 155-160, 2021.

[7] S. Sur and R. B. Ray, "Bitter melon (Momordica charantia), a nutraceutical approach for cancer prevention and therapy," Cancers, vol. 12, no. 8, p. 2064, 2020.

[8] S. A. Bukhari, N. Farah, G. Mustafa, S. Mahmood, and S. A. R. Naqvi, "Magneto-priming improved nutraceutical potential and antimicrobial activity of Momordica charantia L. without affecting nutritive value," Applied Biochemistry and Biotechnology, vol. 188, no. 3, pp. 878-892, 2019.

[9] P. Kumari, R. Verma, G. Nayik, and S. Solankey, “Antioxidant potential and health benefits of Bitter gourd (Momordica charantia L.)," Journal of Postharvest Technology, vol. 5, no. 3, pp. 1-8, 2018.

[10] B. Ijaz, S. A. Jatoi, D. Ahmad, M. S. Masood, and S. U. Siddiqui, "Changes in germination behavior of wheat seeds exposed to magnetic field and magnetically structured water," African Journal of Biotechnology, vol. 11, no. 15, pp. 3575-3585, 2012.

[11] A. Vashisth and S. Nagarajan, "Effect on germination and early growth characteristics in sunflower (Helianthus annuus) seeds exposed to static magnetic field," Journal of Plant Physiology, vol. 167, no. 2, pp. 149-156, 2010.

[12] S. Bansod and M. Rai, "Antifungal activity of essential oils from Indian medicinal plants against human pathogenic Aspergillus fumigatus and A. niger," World Journal of Medical Sciences, vol. 3, no. 2, pp. 81-88, 2008.

[13] P. Sharma, P. Kaur, P. Ghanghas, J. Kaur, and N. Kaushal, "Selenium ameliorates ibuprofen induced testicular toxicity by redox regulation," Reproductive Toxicology, vol. 96, pp. 349-358, 2020.

[14] Y. Bhargavi, P. Sudhakar, V. Rajeswari, and T. Krishna, "Influence of natural liquid organics on growth and biochemical attributes of blackgram (Vigna mungo L.)," Journal of Pharmacognosy and Phytochemistry, vol. 10, no. 1, pp. 759-767, 2021.

[15] S. Noreen, M. Sultan, M. S. Akhter et al., "Foliar fertigation of ascorbic acid and zinc improves growth, antioxidant enzyme activity and harvest index in barley (Hordeum vulgare L.) grown under salt stress," Plant Physiology and Biochemistry, vol. 158, pp. 244-254, 2021.

[16] E. Van Handel, "Rapid determination of glycogen and sugars in mosquitoes," Journal of the American Mosquito Control Association, vol. 1, no. 3, pp. 299-304, 1985.

[17] D. Ustaömer, E. Topaloğlu, B. Yilmaz, H. Serencam, and I. Deniz, "An in vitro study on antifungal properties, total polyphenolic content and antioxidant activity of different 
parts of selected fruit trees," Drvna Industrija, vol. 71, no. 4, pp. 355-363, 2020.

[18] S. Abdelaziz, M. Benamira, L. Messaadia, Y. Boughoues, H. Lahmar, and A. Boudjerda, "Green corrosion inhibition of mild steel in $\mathrm{HCl}$ medium using leaves extract of Arbutus unedo L. plant: an experimental and computational approach," Colloids and Surfaces A: Physicochemical and Engineering Aspects, vol. 619, Article ID 126496, 2021.

[19] L. Spagnuolo, S. Della Posta, C. Fanali, L. Dugo, and L. De Gara, "Antioxidant and antiglycation effects of polyphenol compounds extracted from hazelnut skin on advanced glycation end-products (ages) formation," Antioxidants, vol. 10 , no. 3, p. 424, 2021.

[20] S. Hussain, F. Khan, H. A. Hussain, and L. Nie, "Physiological and biochemical mechanisms of seed priming-induced chilling tolerance in rice cultivars," Frontiers in Plant Science, vol. 7, p. 116, 2016.

[21] C. Vanitha and M. Kathiravan, "Response of pigeonpea to season, halopriming and plant bioregulators intervention in relation to plant physiology and yield potential," Indian Journal of Agricultural Research, vol. 53, no. 2, pp. 190-195, 2019.

[22] P. Rai-Kalal and A. Jajoo, "Priming with zinc oxide nanoparticles improve germination and photosynthetic performance in wheat," Plant Physiology and Biochemistry, vol. 160, pp. 341-351, 2021.

[23] M. Imran, B. Boelt, and K.-H. Mühling, "Zinc seed priming improves salt resistance in maize," Journal of Agronomy and Crop Science, vol. 204, no. 4, pp. 390-399, 2018.

[24] A. Rouhi, M. Tajbakhsh, A. Bernousi, and M. Saeedi, "Study on effect of different primings on seed germination and seedling traits of different pea cultivars," Journal of Agriculture, vol. 90, pp. 1-8, 2011.

[25] K. Rudani, V. Patel, and P. Kalavati, “The importance of zinc in plant growth-a review," International Research Journal of Natural and Applied Sciences, vol. 5, no. 2, pp. 38-48, 2018.

[26] M. G. Mallikarjuna, N. Thirunavukkarasu, R. Sharma et al., "Comparative transcriptome analysis of iron and zinc deficiency in maize (Zea mays L.)," Plants, vol. 9, no. 12, p. 1812, 2020.

[27] H. Zhang, Z. Xu, K. Guo et al., "Toxic effects of heavy metal Cd and $\mathrm{Zn}$ on chlorophyll, carotenoid metabolism and photosynthetic function in tobacco leaves revealed by physiological and proteomics analysis," Ecotoxicology and Environmental Safety, vol. 202, Article ID 110856, 2020.

[28] G. Nayak and N. Altekar, "Effect of a biofield treatment on plant growth and adaptation," Journal of Environment \& Health Sciences, vol. 2, no. 1, pp. 1-9, 2015.

[29] M. Tahjib-Ul-Arif, M. N. Siddiqui, A. A. M. Sohag et al., "Salicylic acid-mediated enhancement of photosynthesis attributes and antioxidant capacity contributes to yield improvement of maize plants under salt stress," Journal of Plant Growth Regulation, vol. 37, no. 4, pp. 1318-1330, 2018.

[30] M. J. Iqbal, P. H. Goodwin, E. D. Leonardos, and B. Grodzinski, "Spatial and temporal changes in chlorophyll fluorescence images ofNicotiana benthamianaleaves following inoculation withPseudomonas syringaepv.tabaci," Plant Pathology, vol. 61, no. 6, pp. 1052-1062, 2012.

[31] M. Kaya, M. Atak, K. M. Khawar, C. Y. Çiftçi, and S. Ozcan, "Effect of pre-sowing seed treatment with zinc and foliar spray of humic acids on yield of common bean (Phaseolus vulgaris L.)," International Journal of Agriculture And Biology, vol. 7, no. 6, pp. 875-878, 2005.
[32] G. Ahmad, R. Mostafa, and O. Ruhollah, "Optimum concentra tion of boric acid and sodium molybdate for enhancing mungbean productivity in Nepal," Agriculture and Agricultural Science Procedia, vol. 2, no. 2, Article ID 60S66, 2016.

[33] A. Mohsin, A. Ahmad, M. Farooq, and S. Ullah, "Influence of zinc application through seed treatment and foliar spray on growth, productivity and grain quality of hybrid maize," Journal of Animal and Plant Sciences, vol. 24, no. 5, pp. 1494-1503, 2014.

[34] Z. Pengel and R. Graham, "Importance of seed zinc content for wheat growth on zinc-deficient soil. I. Vegetative growth," Plant and Soil, vol. 173, pp. 259-266, 1995.

[35] Y. Ramzan, M. B. Hafeez, S. Khan, M. Nadeem, S. Batool, and J. Ahmad, "Biofortification with zinc and iron improves the grain quality and yield of wheat crop," International Journal of Plant Production, vol. 14, no. 3, pp. 1-10, 2020.

[36] T. Samreen, H. U. Humaira, S. Ullah, and M. Javid, "Zinc effect on growth rate, chlorophyll, protein and mineral contents of hydroponically grown mungbeans plant (Vigna radiata)," Arabian Journal of Chemistry, vol. 10, pp. S1802S1807, 2017.

[37] R. Sagardoy, F. Morales, A.-F. López-Millán, A. Abadía, and J. Abadía, "Effects of zinc toxicity on sugar beet (Beta vulgarisL.) plants grown in hydroponics," Plant Biology, vol. 11, no. 3, pp. 339-350, 2009.

[38] M. Gąsecka, M. Mleczek, M. Siwulski, and P. Niedzielski, "Phenolic composition and antioxidant properties of Pleurotus ostreatus and Pleurotus eryngii enriched with selenium and zinc," European Food Research and Technology, vol. 242, no. 5, pp. 723-732, 2016.

[39] S. Afonso, I. V. Oliveira, A. S. Meyer, A. Aires, M. J. Saavedra, and B. Gonçalves, "Phenolic profile and bioactive potential of stems and seed kernels of sweet cherry fruit," Antioxidants, vol. 9, no. 12, p. 1295, 2020. 